\title{
Buying and Selling Transaction in Honesty Canteen According to Islamic Law
}

\author{
$1^{\text {st }}$ Muhammad Ikhlas Supardin ${ }^{1}, 2^{\text {nd }}$ JM Muslimin ${ }^{1}, 3^{\text {rd }}$ Asep Saepudin Jahar ${ }^{2}$ \\ \{muhammad_supardin19@mhs.uinjkt.ac.id ${ }^{1}, j m . m u s l i m i n @ u i n j k t . a c . i d^{1}$, asepjahar@uinjkt.ac.id² $\}$ \\ UIN Syarif Hidayatullah, Islamic Studies Department, Jakarta, Indonesia ${ }^{1}$, UIN Syarif Hidayatullah, \\ Sharia and Law Department, Jakarta, Indonesia ${ }^{2}$
}

\begin{abstract}
The purpose of this research is to find out the law of selling and buying transaction in honesty canteen according to Islamic law. In this research the author used library research method to collect data about selling and buying transaction in the honesty canteen which refer to Islamic law. Some Malikiyyah and Hanabilah scholars are permitted the bai' mu'athah system as long as it is a habit of the local society so no one will be harmed from this transaction, but Shafi'iyyah and some of Hanafiyyah scholars do not permit this transaction if there is no ijab and qabul in transaction between the seller and the buyer. Finally, the results of this research, explained the permitting of transaction agreement in the honesty canteen, because transaction has become a habit without using ijab and qabul at transaction between seller and buyer and called as bai' mu'athah.
\end{abstract}

Keywords: bai' mu'athah, buying and selling, honesty canteen, ijab and qabul, Islamic law.

\section{Introduction}

Islamic law is divided into 3 parts: 1) Sharia, sourced from the Qur'an and Hadith. 2) Fiqh produces fatwas about Islamic law. 3) Qanun, in the form of qadha (rules). Thus, we as Muslims can not do acts that are not sourced from Islamic law. Muamalah is one of the fields of the Islamic law that regulates transactions between humans in meeting their daily needs, such as clothing, food, drinks, and others. Humans can not live alone but need each other to help each other and help each other, the strong help the weak, the rich help the poor, and help each other in community life.

Muamalah law is mubah (permissible) in Islamic law as long as pillars and the conditions are met. The majority of the Fiqh scholars explained in the fiqhiyah rules, "al-Asslu fi almu'ämalah al-ibāhah hatta yadullu al-daīlu' alä tahrimihä". Which means the origin of the law in matters of muamalah is permissible unless there is an argument that forbids it [1].

Buying and selling transactions are one part of muamalah activities that are allowed as long as no one party is harmed between the seller and the buyer. Buying and selling are one means for human life to meet their needs where sellers and buyers need each other. Buying and selling is an agreement to exchange goods and goods of value that are voluntary between the seller and the buyer. The seller gives the goods and the buyer pays the agreed price.

By following the development of the era, the types of buying and selling transactions are also increasing. One form of buying and selling in this era is buying and selling in the honesty canteen. Honest is the main capital for transactions in the honesty canteen, which in this 
transaction eliminates one of the buying and selling pillars namely shighah (ijab and qabul between the seller and buyer). The honesty canteen is a canteen that is very different from the canteen in general. The difference between buying and selling transactions in the honesty canteen lies in the absence of sellers like the canteen in general. Honesty canteens are usually found in some schools and even colleges. Buyers who want to buy goods or food simply put the money in a box that has been provided by the seller and take charge in the other box.

The items sold in the honesty canteen are also not all available, only items that are not too expensive in the form of stationery, snacks, and soft drinks to avoid any loss from the seller. Unlike the canteen in general, which sells all the needs of schools and sells a variety of foods and drinks. Thus the honesty canteen makes it easy for buyers who want to make transactions easily. Some fiqh figures consider buying and selling transactions in this honesty canteen to be the same as a mu'athah transaction, which is an agreement between the seller and the buyer of the price of goods sold without shigoh ijab qabul between seller and buyer [2].

The loss of one of the pillars of buying and selling in the honesty canteen becomes a problem that affects the ownership rights of an item. The covenant is the cause of the strongest and most widespread ownership in human life that requires the distribution of wealth [3]. In this case, buying and selling in an honesty canteen contains an element of gharar (fraud) that can be done by buyers who want to buy or take money back improperly. The discussion about the buying and selling transaction in the honesty canteen cannot be separated from the law of buying and selling. Many contemporary fiqh scholars who follow the times have different opinions about buying and selling in honesty canteens. Some contemporary fiqh scholars allow buying and selling in honesty canteen (bai' mu'athah) by looking at the benefits, others do not allow buying and selling because it contains elements of gharar (fraud).

\section{Research Methodology}

The author uses library research methods, namely as a first step to prepare a (research design), to obtain similar research information, deepen theoretical studies or sharpen methodologies [4]. The author uses this research to find primary data sources related to buying and selling in an honesty canteen according to Islamic law.

Data collection is an attempt to gather relevant information related to buying and selling in honesty canteens according to Islamic law. Information can be obtained from scientific books, research reports, scientific essays, theses, and dissertations, and written sources both printed and electronic [5]. Analysis and interpretation of data in this study using text analysis and discourse [5]. What is meant by text is in the form of language which has contents and forms, both oral and written, while discourse is the context in which language is used?

\section{Result and Discussion}

\subsection{Definition of Buying and Selling}

Buying and selling in language come from the word bai' which means a sale [6], or exchange of item (money) with the item. Like, the seller says: "I sell this item," then the buyer accepts the item and agrees on the price, then the buyer exchanges the item (money) and receives the item. In terminology, buying and selling are an agreement to exchange the item 
(money) with goods of value voluntarily between seller and buyer. The seller gives the item and the buyer pays the agreed price. Following the provisions of Islamic law, it means meeting the pillars, conditions, and matters relating to buying and selling. So that if the pillars and conditions are not met, then the buying and selling are not following Islamic law [7]. The following is the understanding of buying and selling according to the four Imam Madhab.

According to Hanafiyyah, buying and selling contain two meanings, specifically, it is to measure items with currency, namely silver or gold and or the like. While in general, the notion of buying and selling there are twelve kinds of them are these special meanings. Malikiyyah defines buying and selling specifically and generally. Specifically means buying and selling absolutely according to "urf (custom). Whereas in general terms of sale and purchase includes sharf, salam, istisna and others. Shafi'iyyah defines buying and selling according to Islamic law by exchanging assets for assets with certain conditions.

While the definition of buying and selling according to Hanabilah is the exchange of assets with assets or the exchange of using the item with useful goods also for a long time [8]. From the definition of buying and selling above, it can be concluded that buying and selling is the exchange of items (assets) with useful goods by transferring ownership of the items.

Buying and selling are permissible if it fulfills three elements, are: 1) Seller and buyer, 2) Place of exchange (transaction), 3) Words or expressions (shigoh) between seller and buyer, according to the jumhurul 'ulama. According to Hanafiyyah, shigoh is ijab and qabul between seller and buyer, and this is not an element of buying and selling but a pillar of sale [9]. It can also be interpreted that the buying and selling is the exchange of money for money in a certain way or exchange (items) that are desired in a special way that is equally profitable with ijab and qabul or ta'athi, provided that the items must be useful, while not allowed to sell the carcass blood and impurities [10].

Hanafiyyah defines money (property) as printed items and can be used when needed. Money (assets) as a medium of exchange, can prove the financing or ownership of an object for everyone or some of them. Zarqa did not agree with this statement and replaced it with another definition, that is: money is any item that has value among people. Meanwhile, according to jumhurul fuqaha, money (property) is useful, because the exchange of money (property) is for-profit [11].

With the implementation of pillars and the terms of buying and selling, the seller has the right to money (assets) provided by the buyer, while the buyer is also entitled to have the buyer of the item from the seller. Then here the transfer of ownership of an item occurs between the seller and the buyer making the transaction. If one of the pillars and terms of buying and selling are not met, then the item is considered not moving (legitimate). By looking at the era, the buying and selling transactions are also increasing, such as buying and selling online, buying and selling of hoarded items, buying and selling in honesty canteens, and other buying and selling transactions. Are buying and selling that are not fulfilled in pillars and the conditions allowed in Islamic law?.

\subsection{Legal Basic of Buying and Selling}

The law of buying and selling is permissible with propositions from the Qur'an, asSunnah an Nabawiyyah and Ijma. As Allah says:

$$
\text { وَأَحَلَّ اللهُ الْبَيْعَ وَحَرَّمَ الوِبَّا }
$$

It means:

And Allah has justified the selling and buying and forbid usury (Surah Al-Baqarah: 275) 
It means:

And take a witness if you selling and buying (Surah Al-Baqarah: 282)

It means:

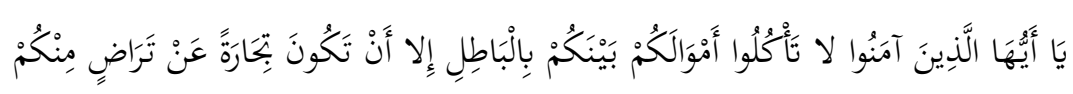

O believers, do not eat your neighbor's property in a false way (not true), except in trades that apply based on mutual liking between you (Surah An-Nisa: 29)

From some of the verses above, Allah has explained about carrying out His commands (buying and selling) and leaving His prohibitions (usury), and never among us take rights (property) that are not ours. Buying and selling have also been explained in as-Sunnah anNabawiyyah as follows:

$$
\text { غأل النبي صلى الله عليه وسلم: أي الكسب أطيب؟ فقال: عمل الرجل بيده، وكل بيع مبرور أي لا خلانة (رواه البزار والحاكم) }
$$

It means:

Prophet Muhammad SAW. once asked. What is the best profession? Rasulullah Saw. replied: "The effort of the human hand itself and every sale and purchase that is blessed, or there is no cheating in it and not betraying. (H.R al-Bazar and al-Hakim)

$$
\text { إنما البيع عن تراض (رواه ابن ماجه) }
$$

It means:

Indeed, buying and selling is only valid (allowed) if you like it. (H.R Ibnu Majah)

The opinion of fiqh scholars is stated that the legal basis for buying and selling is (permissible). Because of humans as social creatures who need each other. The wisdom of buying and selling is mutual assistance in the survival of humanity itself [12]. Humans cannot live alone because they need each other for help between people. In the case of buying and selling, sellers need buyers and buyers need sellers. If the seller does not need the buyer, the items sold will not run out and the buyer will not get the items he needs. How Allah says:

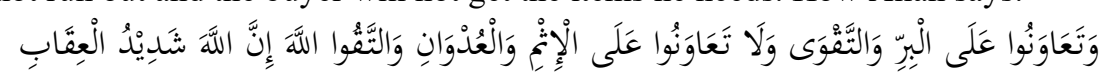

It Means:

And help you in doing good and piety, don't help in sinful and hostile. Fear Allah, verily

Allah is severely tortured. (Surah al-Maidah: 2)

The origin of the law of buying and selling is permissible (permissible) may turn out to be wajib, haram, sunnah or makruh. Depending on the items sold and how to sell the items. For example, the law of buying and selling turns into makruh if the items being traded are cigarettes.

\subsection{Pilar of Buying and Selling}

All forms of buying and selling transactions if one of the pillars is not fulfilled then the buying and selling are considered invalid according to Islamic law. The pillars of buying and 
selling according to Hanafiyyah are ijab and qabul on the exchange of items, or a place of exchange of items (transactions). Another reasoning about the Pillars of buying and selling is the exchange of items (assets) based on like and liking words or deeds, which is called contract (transaction). There are four pillars of buying and selling according to jumhurul ulama: people who have the intention (transaction), shigoh, there are items purchased, there is a replacement exchange rate of items.

A person who has a contract (transaction) is a seller and a buyer. Seller is a person who offers items to other people (buyers), whereas buyers are people who buy items from the seller. With this transfer of ownership of an item from the seller to the buyer. Shigoh is a ijab qabul letter between seller and buyer based on willingness between the two.

According to Hanafiyyah, the one who got along well together was only the willingness of the two parties, the seller and the buyer. There are two indicators that show the willingness of both parties, namely in the form of words (ijab qabul) and in the form of acts of giving each other (handover of items and receiving money) [12], in fiqh is called ba'i mu'athah.

Syafi'iyyah, Malikiyyah and Hanabilah said: the contract (transaction) is the same as buying and selling marriage, like the words: "sell it to me" or "buy it from me" and the other party says: "I buy" or "I sell", because the legal basis for buying and selling is willingness between seller and buyer [11].

Buying and selling are not allowed if there is no shigoh in it, as some fiqh experts define shigoh with ijab qabul. According to fiqh experts, there are five opinions about shigoh:

A Contract (transactions) buying and selling by word.

A Contract (transaction) buying and selling by writing.

A Contract (transactions) buying and selling with a gesture.

A Contract (transaction) buying and selling by auction.

A Contract (transaction) buying and selling with habits.

The type of contract (transaction) with buying and selling habits (mu'athah) is the exchange of items (assets) without using ijab qabul, with ijab without qabul, and or vice versa. Buying and selling are not in conflict with Islamic law even though the items sold are large (large) or small. This opinion was allowed by Hanafiyyah, Malikiyyah, Hanabilah and some Shafi'iyyah [13].

\subsection{Condition of Buying and Selling}

Buying and selling can not be said valid (allowed) what if the following conditions are not met. Fiqh experts classify them as follows:

a. Volunteering between the two parties to the transaction, namely the seller and buyer. If one party is disadvantaged, the buying and selling transaction can be canceled.

b. Sellers and buyers are adults who have a sense. So small children, crazy people, drunk people and people who are sleeping may not make buying and selling transactions. Like a child who has not been able to distinguish between good and bad who want to make a buying and selling transaction must first get permission from their parents. Then the trading transaction is permitted by Abu Hanifah.

c. The items sold must be available when making a transaction. Types of buying and selling transactions that are postponed are not allowed, such as buying and selling fruit that has not yet grown from the tree, because it can harm either party either the seller or the buyer.

d. The items sold must be self-owned (seller). Illegal buying and selling (allowed) if the item belongs to someone else, such as buying and selling river water. 
e. The goods sold must be known for their form and nature. The scholars have several opinions about the buying and selling of ghosts (invisible) whose nature and form are unknown. The majority of experts view buying and selling as illegal (allowed).

f. The items sold must be obtained legally. Unauthorized (allowed) buying and selling from looting, fraud, theft, corruption, and others. As the Prophet Muhammad said, that something that grows or raised illegally, then hell is the most suitable place. (H.R Ahmad)

g. The goods sold must be pure. Forbidden buying and selling of porke, carcasses, liquor, blood and other substances that are forbidden [14].

h. The price of items sold must be clear. When the buyer wants to buy the item, but the price of the item is not clear, then buying and selling is not allowed.

\section{Honesty Canteen}

\subsection{Honesty Canteen Theory}

Canteen in the language is a place to sell food or drinks [15]. Canteens can usually be found in various places, such as schools, offices, colleges, and others. The benefit of the canteen is to sell the various needs of students, teachers, workers, and others so that they benefit from the seller's results. Canteen in general as a means of gathering place when the time is rest, with food, drinks and various other types of products that have been provided by the canteen (seller). Honestly in the language is trustworthy, not lying, upright, saying what it is, not cheating, sincere, sincere. While honesty is the nature of honesty, honesty. Honesty will bring good luck [16].

Honesty is a term of one's behavior, which consists of equality of words and actions, lying and deceiving others is not commendable. Honesty is intended to be a person's behavior not to lie to themselves and others. The value of honesty in daily life is one of the first and most important foundations for avoiding anti-corruption education [17].

Honesty Canteen is a canteen that sells snacks and drinks. Honesty Canteen does not have a seller inside the canteen itself. A money box has been provided in the honesty canteen to accommodate payments from buyers. If there is a change, the buyer calculates and takes the change himself from the box provided. In this canteen, buyer awareness is highly required to shop by paying and taking change if it is excessive, without having to be monitored by canteen employees.

Honesty canteen is an effort to educate students' morals to behave honestly. Honesty canteen is one form of educational activities in realizing an honest character towards students, where they take food or drink items and put money into the boxes provided by the canteen manager and if there is change, the students themselves count the change and take it in the box has been provided. Students can develop honesty in themselves to avoid dishonesty (corruption).

The products sold in the honesty canteen are in the form of entrusted food originating from the home industry, ready to eat food and drinks like food and drinks in the school canteen. The honesty canteen itself does not sell stationery because these items have already been sold at the school cooperative. Every student who wants to buy food or drinks can directly buy it in the honesty canteen because there is already a wide range of ready-to-eat 
food and drinks available. Also, food from entrusted or home industries such as square rice, fried noodles, fried foods, and others.

How to transact in an honesty canteen is the same as buying and selling transactions in general, what distinguishes buying and selling in an honesty canteen is the absence of sellers like buying and selling in general. The manager of the honesty canteen (seller) has provided two boxes for transactions, the first box to put money in and the second box to make a change. Buyers only come and pay without saying the word ijab qabul with the seller, the buyer only puts money into the box that has been provided by the seller, if you get a chance on a buying and selling transaction at the honesty canteen, the buyer takes the change in the box provided by the seller.

One of the pillars of buying and selling according to Hanafiyyah is a ijab qabul from the seller and buyer. In this honesty canteen, there are no sellers like buying and selling in general. Transactions in the honesty canteen are similar to the contract (transaction) of buying and selling with the local community habits. Fiqh experts call it bai' mu'athah, which is a contract (transaction) of buying and selling without using shigoh ijab qabul between the seller and the buyer when making a transaction, so it has become a habit of the local community to carry out this buying and selling transaction.

Transactions like this have become a habit for students to train the mind and character of early childhood to avoid corruption. Honesty is the door to goodness, so educate children as early as possible, to be honest. Honesty canteen cannot be compared to ordinary canteens. The usual canteen aims to benefit from the sales process, while an honest canteen is an effort to educate students about the value of honesty. The purpose of honesty canteen is education (not just teaching) value. Through honesty canteen, the students are not to learn about the economy, but rather to find out the meaning of honesty in children's education. If the honesty loss canteen (bankrupt), meaning that the business must be closed [18]. Small and large businesses can not be separated from the name of profit and loss. Profits and losses will always be found by traders or entrepreneurs in each run of their business. Besides that, business actors must find ways to get profits for their businesses and do not want to get losses.

Buying and selling transactions in the honesty canteen there are no sellers in it, so this is what causes problems. The problem that occurs in various honesty canteens is that some buyers still cheat and do not act honestly when conducting buying and selling transactions in the honesty canteen so as to reduce the income in the honesty canteen. Some buyers also know and memorize the price list of each item sold in the honesty canteen, but there are still buyers who do not pay or take undue returns.

The negative impact of honesty canteen is the supervision of the seller when the buyer wants to make a sale and purchase transaction. The honesty canteen is also a programmed and directed activity carried out by the school, which aims to teach and develop honest character values. But in addition to the value of honest character, the value of responsibility must also be instilled in early childhood, because by planting honest nature from an early age reduces the impact of corruption [19]. The honesty canteen also has a positive value, which makes it easy for students (buyers) to trade and buy transactions in the honesty canteen so that buyers only put money into the box provided by the seller without waiting in line to pay the seller. On the other hand, it also trains the character of children to be honest and instill the value of honesty. 


\subsection{Bai' Mu'athah}

Bai' mu'athah is an agreement between two parties that transact (seller and buyer) of prices and items, then the buyer pays the items (sold) to the seller voluntarily between the seller and buyer without saying the word (shigoh) ijab qabul between the seller and buyers [20]. As an example: the buyer takes the item from the seller, then pays the item without saying a word or signal, even if the item is a lot or a little [10]. The experts of fiqh have several views about ba'i mu'athah.

The opinion of Hanafiyyah, Malikiyyah, and Hanabilah (more favored), that ba'i mu'athah is allowed during this buying and selling transaction on the basis of willingness between seller and buyer. Every buying and selling transaction is permitted on a voluntary basis because buying and selling transactions in the market also do not use qabul consent.

The specialization of some fiqh scholars such as Ibn Sarij and Ruyani from the Shafi'iyyah and Karkhi from the Hanafiyyah circles is contrary to allowing mu'athah. As is the case, it has become a habit to give a pound with and take a pair of bread without saying ijab qabul. Hanabilah allows ba'i mu'athah on condition that it does not end the answer from the requesting (buyer), such as: "take this (item) with one dirham", or do not delay the request (seller), such as: "Give me bread with one dirham ". Because if the ijab qabul is ended, then there will be consideration of the first abuse [21].

Syafi'iyyah's opinion that buying and selling are absolutely not allowed, even if the items sold are many or few. Buying and selling transactions are allowed on the basis of willingness between the seller and the buyer, that is, something will be vague and unknown without ijab and qabul, so must be said especially if you want to prove the transfer of ownership of an item. For example, witness testimony will not be received before a judge, unless he has heard the direct words [20].

\section{Conclusion}

The Honesty Canteen is a canteen that sells food and drinks, like the canteen in general. Named honesty canteen because there are no sellers when buying and selling transactions. Food and drinks are available at the place provided by the honest canteen manager. In the honesty canteen, two boxes of money have been provided for buying and selling transactions between sellers and buyers who want to buy food or drinks. Buyers calculate and take their own change that is available in the change box without being guarded by the seller.

As mentioned above regarding the establishment of an honesty canteen, harmonious terms and conditions of buying and selling are still not met in the buying and selling of an honesty canteen. In Islamic law, buying and selling are said to be valid (permissible) if the pillars and the conditions are met. In addition, fiqh scholars are still debating about shigoh buying and selling by deeds, or what is called bai' mu'athah (Muslich, 2010).

Bai' mu'athah is the exchange of items (assets) with items between the two parties, namely the seller and the buyer without using the ijab qabul in words. As we often find in some supermarkets or small markets, where there is no ijab qabul with words between sellers and buyers.

An overview of Islamic law regarding legitimate (permissible) or not the buying and selling transaction, can be seen from the emergence of several debates of opinion among fiqh scholars. Sayyid Sabiq argues that buying and selling transactions can be done with ijab and 
qabul, except for cheap items, if done does not endanger the buying and selling transaction without user ijab and qabul, but only the giving of items. May leave the practice if it has become a habit [23].

Furthermore, the author can conclude that buying and selling transactions in the honesty canteen are legal (permissible), because some fiqh scholars such as Hanafiyyah, Malikiyyah, and Hanabilah allow buying and selling transactions without using ijab qabul in words. The law of buying and selling transactions in the honesty canteen is permissible if the activity has become a habit of the local community and on the basis of willingness between the seller and buyer. What is meant by sellers in the honesty canteen is the owner of the honesty canteen itself, such as schools, organizations, offices and others? In this study, the pillars of buying and selling have been fulfilled, namely: Both parties to the transaction (seller and buyer), items sold, and shigoh (ijab qabul) with words, deeds or with a gesture. Then the sale and purchase transaction is said to be invalid (permitted) if one of the guidelines is not fulfilled.

Rasulullah Saw., Forbade several buying and selling transactions containing gharar in it, which makes humans eat property that is not their property in a false manner (wrong way) so that jealousy, conflict, and hostility arise among Muslims [24]. There is no element of gharar in the buying and selling transaction in the honesty canteen because the items and prices are clear, so buying and selling in the honesty canteen is allowed. Buying and selling transactions in the honesty canteen as well as ba'i mu'athah, namely buying and selling without using ijab qabul in words.

After conducting an analysis of the law of buying and selling in the honesty canteen, the author draws the conclusion that the origin of the Islamic law is permissible, as long as there is no proposition that prohibits it. The buying and selling agreement in the honesty canteen is permissible as long as it has become between the seller and the buyer in transactions in the honesty canteen without user ijab and qabul, but on a voluntary basis between the seller and buyer. The purpose of establishing an honest canteen is to train young children to be honest and stay away from corruption. Besides that, the honesty canteen does not have the element of gharar (cheating) because the price and the items have clearly existed (its appearance) without any seller when transacting in the honesty canteen.

\section{Acknowledgments}

We would like to thank all of the academic community of the Graduate School of UIN Syarif Hidayatullah Jakarta, especially to Prof. Dr. Jamhari, MA. as the director of the Graduate School of UIN Syarif Hidayatullah Jakarta, Dr. JM. Muslimin, MA as the supervisor and thank to the Ministry of Religion of the Republic of Indonesia for giving us a PMLD scholarship.

\section{References}

[1] Djazuli, kaidah kaidah fikih, pertama ed.: kencana, 2006.

[2] Rachmat Syafei, Fiqh Muamalah. Bandung: Pustaka Setia, 2001.

[3] Harun, Fiqh Muamalah. Surakarta: Muhammadiyah University Press , 2017.

[4] Mestika Zed, Metode Penelitian Kepustakaan. Jakarta: Yayasan Obor Indonesia, 2008.

[5] Amir Hamzah, Metode Penelitian Kepustakaan. Malang: Literasi Nusantara, 2019.

[6] Ahmad Warson Munawir, Al Munawir Kamus Arab-Indonesia. Yogyakarta: Pustaka Progressif, 1997. 
[7] Hendi Suhendi, Fiqh Muamalah, 1st ed. Jakarta: Rajawali Pers, 2016.

[8] Abdulrahman Al Jaziri, Fiqih Empat Mazhab, 3rd ed. Semarang: Asy Syifa', 1994.

[9] Wahbah Zuhaili, al-Mu'amalat al-Maliyah al-Mu'asiroh. Damaskus: Darul Fikr, 2002.

[10] Wahbah Zuhaili, Fiqh al-Islam wa Adillatuhu, 5th ed. Mesir: Darul Fikr, 1984.

[11] Ali Jum'atu Muhammad, Mausu'atu Fatawa al-Mu'amalat al-Maliyah.: Darussalam li at-Toba'ah wa an-Nasyr wa at-Tauzi' wa at-Tarjamah, 1430.

[12] Syaifullah, "Etika Jual Beli Dalam Islam," Jurnal Studia Islamika, vol. XI, no. 2, p. 375, 2014.

[13] Abu Malik Kamaluddin al-Sayyid Salim, Shahih Fiqh Sunnah wa Adillatuhu.: al-Maktabah alTaufiqiyah, 2002.

[14] Siti Mujiatun, "Jual Beli Dalam Perspektif Islam: Salam dan istisna'," Jurnal Riset Akuntansi dan Bisnis, vol. XIII, no. 2, p. 206, 2013.

[15] Qonita Alya, Kamus Bahasa Indonesia. Jakarta: PT Indahjaya Adipratama, 2009.

[16] Umi Chulsum dan Windy Novia, Kamus Besar Bahasa Indonesia. Surabaya: Kashiko, 2014.

[17] Chatrina Darul Rosikah dan Dessy Marliani Listianingsih, Pendidikan Anti Korupsi. Jakarta Timur: Sinar Grafika, 2016.

[18] Fitiria Martanti, "Penanaman Nilai-nilai Kejujuran Melalui Media Kantin Kejujuran di Pondok Pesantren Al Hikmah Semarang," SOSIO DELEKTIKA- Jurnal Ilmu Sosial-Humaniora, vol. II, no. 1, p. 47, 2017.

[19] Sutarto dan Ikhwanuddin Ahmad Jaedun, "Model Pendidikan Karakter di SMK Melalui Program Pengembangan Diri dan Kultur Sekolah," Jurnal Pendidikan Teknologi dan Kejujuran, vol. XXII, no. 2, p. 166, 2014.

[20] Abdul Karim bin Ali bin Muhammad Al-Namlah, Syarhu Raudhatu al-Nazir fi Ushul Fiqh, 4th ed.: Darul 'Ashimah li al-Nasyr wa al-Tauzi', 1996.

[21] Wuzaroti al-Auqaf wa al-Syu un al-Islamiyyah, al-Mausu'atu al-Fiqhiyyah, 5th ed., 2005.

[22] Ahmad Wardi Muslich, Fiqh Muamalat. Jakarta: Amzah, 2010.

[23] Sayyid Sabiq, Fiqh as-Sunnah. Mesir: al-Fathu li al-I'lamy al-Araby, 1983.

[24] Ismail Nawawi, Fikih Muamalah Klasik dan Kontemporer. Bogor: Ghalia Indonesia, 2012.

[25] Ali Jum'atu Muhamad, Mausu'atu Fatawa Al-Muamalat Al-Maliyah, 7th ed. Beirut: Dar AlSalam, 2009. 